\title{
Fishers' resource mapping and goliath grouper Epinephelus itajara (Serranidae) conservation in Brazil
}

\author{
Leopoldo Cavaleri Gerhardinger ${ }^{1,2}$, Mauricio Hostim-Silva ${ }^{3}$, Rodrigo Pereira Medeiros ${ }^{4}$, \\ José Matarezi ${ }^{2}$, Áthila Andrade Bertoncini ${ }^{1,5}$, Matheus Oliveira Freitas ${ }^{6}$ \\ and Beatrice Padovani Ferreira ${ }^{7}$
}

Goliath grouper (Epinephelus itajara) aggregations and relative abundances were described and mapped through the use of fishermen's local ecological knowledge in Babitonga Bay in southern Brazil. Six well-experienced informants were asked to individually provide information about goliath grouper abundance and distribution, drawn over a satellite image of the study area, which was later overlaid and gathered into a final map. According to our informants, the goliath grouper occurs along a broad salinity and depth range, from shallow estuarine areas (less than $5 \mathrm{~m}$ deep) with high freshwater input (smaller individuals, up to $150 \mathrm{~kg}$ ) to coastal marine-dominated environments (at least $35 \mathrm{~m}$ deep); (larger individuals more common, frequently reaching more than $300 \mathrm{~kg}$ ). Fishermen referred to goliath groupers inhabiting hard substrates such as rocky reefs around islands and continental shores, submerged rocky outcrops and shipwrecks (juveniles and adults). At least two aggregation sites mapped (ranging from 2 to 60 individuals) could be concluded as spawning aggregation sites through evidence of high abundance and spawning activity. Priority research and conservation targets were identified and discussed for Babitonga Bay (e.g., design of a tagging experimental program and establishment of a marine protected area). Fishers' resource mapping provided a means of exchanging information among various disciplines while maintaining methodological rigor in a clear and straightforward way of presenting fishers' knowledge. The use of fishers' sketch maps is a promising tool for marine conservation in Brazil, with special regard to adaptive co-management regimes, where frequent environmental re-evaluations are needed.

A abundância relativa e agregações de meros Epinephelus itajara foram descritas e mapeadas através do conhecimento ecológico local de pescadores da baía Babitonga, sul do Brasil. Seis informantes muito experientes desenharam individualmente sobre uma imagem de satélite da área de estudo informações sobre abundância e distribuição de meros, seguindo-se de uma sobreposição das imagens em um mapa final. O mero ocorre ao longo de uma larga faixa de salinidade e profundidade (principalmente juvenis), de áreas estuarinas rasas (menos que $5 \mathrm{~m}$ de profundidade) com alta incidência de água doce, até ambientes costeiros marinhos (ao menos até $35 \mathrm{~m}$ de profundidade); (indivíduos maiores são mais comuns, alcançando mais de $300 \mathrm{~kg}$ ). A espécie é também encontrada habitando substratos consolidados como recifes rochosos ao redor de ilhas e continente, parcéis submersos e emersos e naufrágios. Ao menos duas das agregações mapeadas (variando de dois a 60 indivíduos observados) puderam ser consideradas agregações reprodutivas através de evidências de alta abundância e atividade reprodutiva. Ações de pesquisa e conservação foram identificadas e discutidas para a baía Babitonga. O mapeamento de recursos possibilitou uma forma de trocar informações entre várias disciplinas, mantendo rigor metodológico e apresentando o conhecimento dos pescadores em uma forma clara e direta. $\mathrm{O}$ uso do mapeamento é uma ferramenta promissora para a conservação marinha, com atenção especial para abordagens de co-gestão adaptativas, onde frequentes reavaliações ambientais são necessárias.

Key words: Sketch maps, Traditional ecological knowledge, Spawning aggregation, Ethnoecology, Babitonga Bay.

\footnotetext{
${ }^{1}$ Associação de Estudos Costeiros e Marinhos, ECOMAR. Rua Dr. José André da Cruz, 539, Nova Coréia, $45900-000$ Caravelas, BA, Brazil. leocavaleri@gmail.com

${ }^{2}$ Universidade do Vale do Itajaí, CTTMar, Laboratório de Educação Ambiental. Rua Uruguai, 458 - Caixa Postal 360, 88302-202 Itajaí, SC, Brazil. ${ }^{3}$ Universidade Federal do Espírito Santo, CEUNES, Departamento de Ciências da Saúde, Biológicas e Agrárias. Rua Humberto de Almeida Francklin, 257, 29933-415 São Mateus, ES, Brazil.

${ }^{4}$ Universidade do Vale do Itajaí. Núcleo de Estudos Sociais e Politicos, NESP. Rua Uruguai, 458 - Caixa Postal 360, 88302-202 Itajaí, SC, Brazil.

${ }^{5}$ Universidade Federal de São Carlos, Centro de Ciências Biológicas e da Saúde, Programa de Pós-graduação em Ecologia e Recursos Naturais. Rodovia Washington Luiz, Km 235, Monjolinho, Caixa Postal 676, 13565-905 São Carlos, SP, Brazil.

${ }^{6}$ Universidade Estadual de Santa Cruz, UESC. Programa de Pós-Graduação em Sistemas Aquáticos Tropicais. Rodovia Ilhéus-Itabuna, Salobrinho, 45662000 Ilheus, Bahia, Brazil.

${ }^{7}$ Universidade Federal de Pernambuco, Departamento de Oceanografia. Av. Arquitetura, s/n, Cidade Universitária, 50670-901 Recife, Pernambuco, Brazil.
} 


\section{Introduction}

Data required for decisions in marine resource management are frequently regarded as insufficient or inexistent, especially when considering small geographic scales (Johannes, 1998; Anuchiracheeva et al., 2003; Drew, 2005). Whereas scientific knowledge is well organized and documented, allowing a broad view of ecosystem functioning on a large-scale, fishers possess detailed ecological knowledge on a local geographic scale (Johannes et al., 1998; Marques, 2001). Ecological knowledge of local resource users may be a unique source of information in remote areas, far from research centers, where local ecological attributes and processes are poorly known (Aswani \& Lauer, 2006). Fishermen's local ecological knowledge (LEK) and traditional practices can thus play a central role in local marine resource management (Haggan et al., 2007).

In the last two decades, interest in fishermen's LEK has increased significantly (Ruddle, 1994; Huntington, 2000; Diegues \& Arruda, 2001; Davis \& Wagner, 2003). Examples of such studies in Brazil include folk taxonomy (Paz \& Begossi, 1996), research examining fishers' knowledge of feeding (Costa-Neto et al., 2002), reproductive cycles (Silvano et al., 2006), general aspects of the ecology of marine fishes (Gerhardinger et al., 2006) or ecosystems, and behavior and social-ecological changes (Seixas \& Berkes, 2003).

The above studies have developed methodologies for documenting and using LEK, as well as understanding the political and institutional structures necessary for the management of local resources (Davis \& Wagner, 2003). Nevertheless, methodological barriers are often considered some of the major limiting factors for effective engagement of LEK in research and management of marine natural resources (Hamilton \& Walter, 1999; Neis et al., 1999; Huntington, 2000; Baelde, 2001; Davis \& Wagner, 2003; Gerhardinger et al., 2007). The use of resource user sketch maps is a promising tool that has increasingly been a part of ethno-ecologists' approaches to fishers' LEK documentation (Calamia, 1999; Aswani \& Lauer, 2006; Begossi, 2006; Langley, 2006; Gerhardinger et al., 2007). This method provides a practical system for gathering a variety of information such as abundance, behavior and migration of local marine resources, and stakeholder spatial use of the seascape (Calamia, 1999; Aswani \& Lauer, 2006).

In our study, fishers' sketch maps were used to document goliath grouper, Epinephelus itajara (Lichtenstein, 1822), habitat use and aggregations on the coast of South Brazil. The goliath grouper, E. itajara, is the largest Atlantic grouper (Serranidae), reaching more than $2 \mathrm{~m}$ in length and weighing up to $455 \mathrm{~kg}$ (Bullock et al., 1992). This species inhabits tropical shallow and coastal waters of the Americas and western Africa (Craig et al., 2008). The species is mangrovedependent, showing a size-related habitat shift (Frias-Torres, 2006). Larvae from the pelagic environment settle in shallow coastal waters. Benthic juveniles live in estuaries, usually associated with red mangrove shorelines of high structural complexity, and adults occur in offshore areas (less than $50 \mathrm{~m}$ deep), such as coral and rocky reefs and artificial structures (Frias-Torres, 2006; Koenig et al., 2007). E. itajara is now threatened by over-fishing throughout its geographical range. Its large size, slow growth, late maturity and habit of forming spawning aggregations all contribute to its vulnerability, while habitat degradation of mangrove nursery areas (Frias-Torres, 2006) has also caused serious problems (Bullock et al., 1992). The goliath grouper is also recognized as a critically endangered species by the World Conservation Union (TakChuen \& Ferreira, 2006). Fishing for goliath grouper has been prohibited since 1990 in U.S. waters and 1993 in the Caribbean (Sadovy \& Eklund, 1999). In Brazil, protection was implemented in 2002, when the regulation established a five-year ban on harvesting, possession and commercialization of this species. The moratorium has recently (2007) been expanded until 2012. During this period, research is needed in order to further evaluate its conservation status throughout its Brazilian range (Hostim-Silva et al., 2005; Gerhardinger et al., 2007).

Here, we discuss how LEK and sketch maps may be useful as tools for goliath grouper spawning aggregation study and conservation in the country. We also provide a description of some of the ongoing initiatives and prospects for E.itajara conservation in Brazil.

\section{Material and Methods}

\section{Study Area}

Babitonga Bay is one of the largest estuarine systems of South Brazil (Fig. 1) (26 $00^{\circ}$ - 26'40'11'S and 48 '28'56" $\left.49^{\circ} 00^{\prime} \mathrm{W}\right)$. The bay has approximately $130 \mathrm{~km}^{2}$ of water surface and $6 \mathrm{~m}$ of average depth, although some deep navigation channels are as much as $30 \mathrm{~m}$ deep. Several rocky and fluvial islands are found within the bay which has several areas of rocky and muddy bottoms. Coastal vegetation is dominated by mangroves (Avicennia schaueriana, Laguncularia racemosa, Rhizophora mangle), marshes and tropical Atlantic rainforest. Babitonga Bay shelters approximately 33 communities, 1089 fishermen and 493 small boats, of which only $67 \%$ are motorized (Ibama, 1998). The principal fishing gear used consists of gillnets, bottom trawling nets, longlines, cast-nets and gerival (tide/motor-driven net which targets shrimp). The main fishing resources are finfishes (Ariidae, Carangidae, Mugilidae, Paralichthyidae, Pomatomidae, Sciaenidae and Serranidae), shrimp, oysters, clams and crabs, among others (Ibama, 1998; Pinheiro \& Cremer, 2004, Gerhardinger et al., 2006a).

\section{Data collection and analysis}

In order to identify the most knowledgeable fishers with regard to E. itajara ecology and distribution, each one of the five main local fishing communities were visited between December 2002 and July 2004. Visits lasted a minimum of six hours, during which we approached fishers, fish markets and 


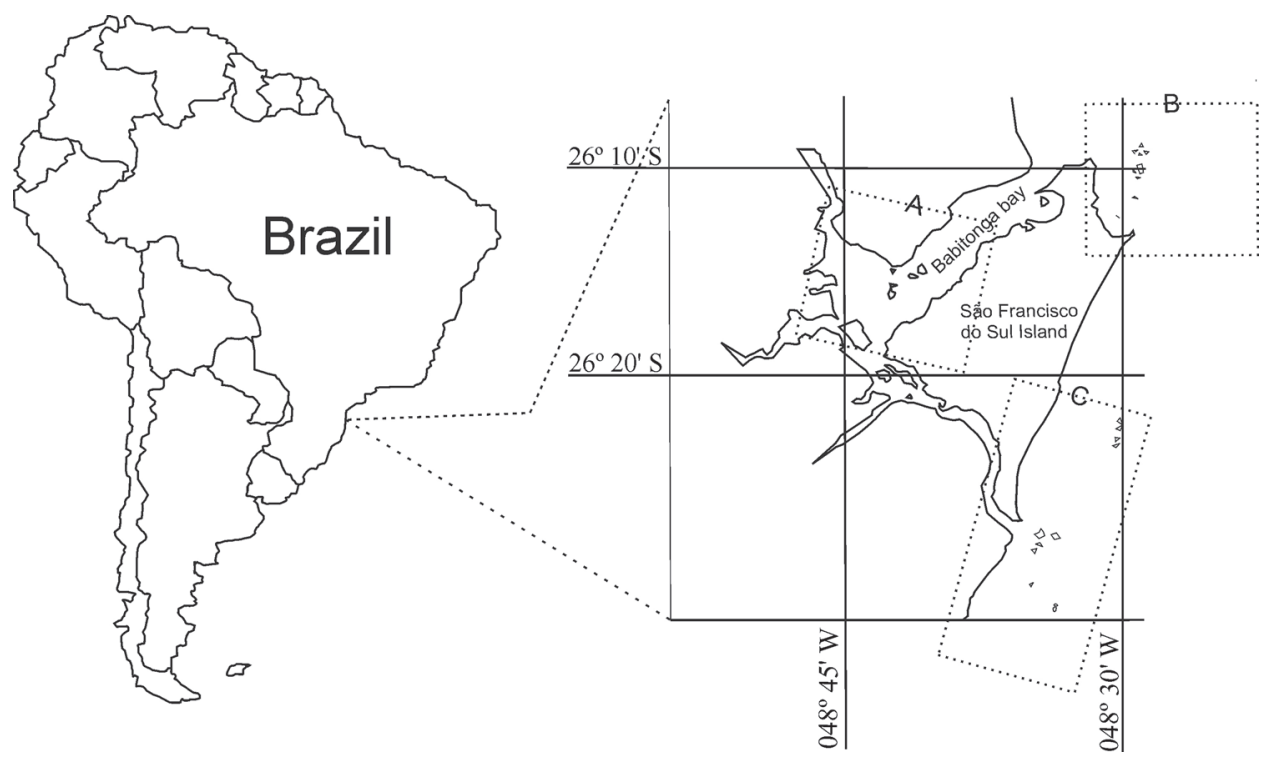

Fig. 1. São Francisco do Sul Island and Babitonga bay, Southern Brazil. Detached areas (a, b and c) are those detailed in Fig. 2.

fishers' association staff and asked them to indicate those who would most likely provide us with the best information on E. itajara. A small number of fishers were recognized as "goliath grouper experts" at each community, so that expert references rapidly converged to a few names (two to three) in each locality. A final selection was made by the corresponding author (LCG) in possession of a final list of fifteen E. itajara specialists indicated by the community. Six "informants" were selected, giving preference to those fishers showing in-depth knowledge of goliath grouper life traits during our preliminary conversations, ability to communicate with the research team, community recognition and, most importantly, willingness to join the project. Other experts could not be engaged in the project because of their advanced age and consequent limitation in examining our maps.

Both long-line and spear fishing informants were engaged in order to register a broader picture of the species' ecological attributes in both estuarine (long-line fishing areas) and offshore marine environments (spearfishing areas). The research team was well received by the specialists in their home, and a strong rapport was established between the informant and interviewer.

Of the six informants selected (mean age of 49 years), two are long-line fishers in the inner Babitonga Bay (estuarinedominated environment) and four are spearfishers in the outer bay (marine dominated and rocky reef environment). Longline fishing has been practiced in the area for at least three generations, and it uses a fishing gear devised to target mainly goliath groupers and other large finfish. Spearfishing, however, is a much newer practice (few decades) (Gerhardinger et al., 2006b). Each informant was interviewed individually with previous consent. On every occasion, the objectives of the present project were presented and discussed before the data collection.

Each informant was provided with a satellite image of the study area $(47 \times 56 \mathrm{~cm})$ (same geographical area of Fig. 1). Information was then drawn with a pen on a transparent plastic overlay sheet on the image. Informants were asked to draw throughout the map the present most abundant goliath grouper sites. Goliath grouper abundance categories were: 1 mark = occasional, 2 marks $=$ abundant, 3 marks $=$ very abundant. The areas with no marks were considered as of rare/no occurrence. Informants were also asked to recall and mark each occasion where at least two goliath groupers were sighted at the same place. Thus, six individual overlays were produced and none of the informants had access to the overlays of other fishers, in order to avoid influences.

The six overlays were condensed into a final layer, prepared with CorelDraw 12. When two informants classified the same site, a mean value was calculated. Values were rounded to the upper category. In order to preserve the precise location of the indicated sites, neither scales nor names (localities and islands) are presented.

\section{Results}

\section{Goliath grouper distribution and habitat use}

According to our informants, E. itajara is present in areas of estuarine- (Fig. 2a) to marine-dominated environments (Fig. $2 b)$. The species is associated with rocky bottoms, especially coastal and inner bay islands. At a few sites, the species was observed at the continent's rocky shores (Fig. 2a, three-row markings at upper left corner; $2 b$, one-row marking at bottom left). Shipwrecks (Fig. 2b) and outcrops (Figs. 2a-b-c) are also 
sites normally inhabited by the goliath grouper. Inner bay individuals reported by our long-line fishing informants weighed up to approximately $150 \mathrm{~kg}$, but smaller fish (less than $40-60 \mathrm{~kg}$ ) are most commonly caught according to our informants. Meanwhile, outer goliath groupers reported by spearfishermen were frequently larger than $300 \mathrm{~kg}$.

The deepest reported occurrence of goliath grouper was at a shipwreck located at a depth of $35 \mathrm{~m}$, where the fish was sighted during a scuba dive (Fig. $2 b$ ). There are very few outcrops, islands and shipwrecks deeper than $30 \mathrm{~m}$ in the study area, and most of the information provided by the spear fishers (Figs. 2b-c) involved depths of more than $20 \mathrm{~m}$. However, in the inner part of Babitonga bay, there are some deep (deeper than $30 \mathrm{~m}$ ) outcrops and channels where longline is employed and where E. itajara is known to occur according to our informants.

The highest relative abundance of E. itajara was in the area represented as a very large rocky outcrop with small islands in the outer bay (Fig. 2c, bottom). The largest aggregations, and most numerous ones, were registered at this same site.

Spear fisher informants indicated that in the "good old days," goliath groupers were present in much higher abundance along some coastal islands and shallow outcrops (Fig. 2b, area encompassed by the left bottom quarter of the map; Fig. 2c, archipelago at the center of the map). According
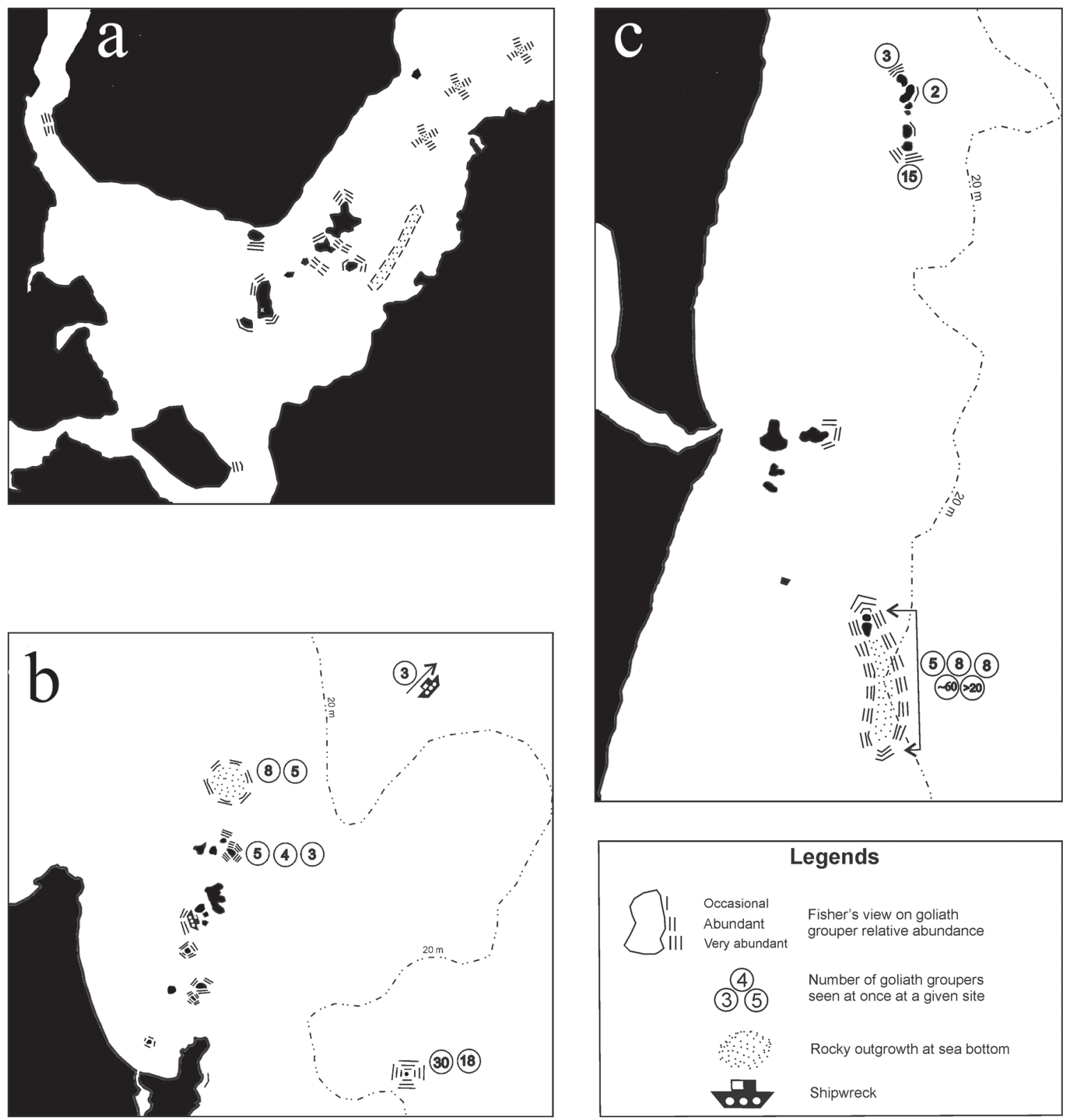

Fig. 2. Fishermen resource mapping of goliath grouper relative abundances and aggregations at Babitonga Bay (a) and surrounding areas (b and $\mathrm{c}$ ). 
to our spear fisher informants, the continuous increase of fishing effort has drastically diminished the abundance of $E$. itajara and other species along these surrounding fishing grounds.

\section{Goliath grouper aggregations}

Spear fishers' information on E. itajara aggregations (Figs. $2 b-c)$ indicated the sites where goliath groupers were sighted in small groups. Such data corroborates the data on relative abundance. Among eight indicated aggregation sites, five received three marks (very abundant). Three sites are distinguished by the high number of aggregations pointed out and the amount of fish seen on each occasion (Fig. 2c, islands and adjacent rocky submerged reefs on the bottom of the figure; Fig. $2 b$, right bottom corner; Fig. $2 b$, islands and submerged reefs at the center of the figure).

The deepest $E$. itajara aggregation ( $\mathrm{n}=3$ individuals) was seen at a shipwreck at $35 \mathrm{~m}$ deep. The greatest density of fish ( $\mathrm{n} \approx 60$ individuals) was seen at a long stretch of submerged rocky reefs at depths varying from 8 to $18 \mathrm{~m}$ (Fig. $2 \mathrm{~b}$, right bottom corner). Another site with a remarkable $E$. itajara density record was that of Fig. $2 \mathrm{~b}$ (right bottom corner), at $26 \mathrm{~m}$. Several other aggregation sites were recorded in Figs. $2 \mathrm{~b}-\mathrm{c}$ with a variable number of individuals sighted.

Spear fishers were not familiar with rocky reef sites located in the inner bay. The only informant who had practiced spear fishing in this area a few decades ago was our senior informant (83 years old), at times when water transparency was greater in the inner bay (Gerhardinger et al., 2006a).

\section{Discussion}

\section{Goliath grouper distribution and habitat use}

Epinephelus itajara has a preference for holes, caves and places where they can find shelter (Sadovy \& Eklund, 1999). Through the observation of our sketch maps, we conclude that $E$. itajara is frequently found inhabiting rocky bottoms (rocky shores and outcrops) and shipwrecks. However, the species may also occur inside the bay, associated with structures formed by the accumulation of drift wood, brought from the upper estuary during strong storms (Gerhardinger, 2006b). Our informants were unable to differentiate locations where larger (deeper than 40-60 kg) and smaller (less than 40$60 \mathrm{~kg}$ ) individuals are found. However, when comparing knowledge of spearfishers $v s$. long-liners, a shift in the size of observed fish is evident, with smaller individuals more commonly seen in estuarine rather than offshore areas.

In the Caribbean and Gulf of Mexico, E. itajara is usually found in waters up to $40 \mathrm{~m}$ deep, with few records at depths of 50-90 m (Sadovy \& Eklund, 1999). Our data show that $E$. itajara may occur deeper than $30 \mathrm{~m}$, but it was not possible to draw conclusions on the exact depth range for the goliath grouper, based solely on the sketch maps. Spearfishing is usually limited to shallow waters, practiced to 20-25 m deep, and this depth range was the limit of informants' knowledge.
Analyzing the regional fishing statistics (Univali, 2002), we found that the goliath grouper is apparently not so vulnerable to the industrial fleet operating along the continental platform, as only a total landing of $513 \mathrm{~kg}$ (no number of individuals available) of E. itajara was registered for the fleets with double bottom-trawl gear in 2002.

The data on species relative abundance have contributed to the identification of priority areas for further research and conservation in our region. The use of abundance categories is tentative and was an attempt to facilitate the comparison of our informants' knowledge. Although this method provides a simple and straightforward way of documenting and presenting the data, we recognize that the perception of different abundance levels may have possibly varied among our informants. This possible bias should be taken into account because fishers of different ages can have different perceptions of marine resource integrity, a phenomenon known as "shifting baselines" (Pauly, 1995). Shifting baselines are intergenerational changes in the way people perceive the state of the environment. Gradual changes tend to be overlooked such that today's generations fail to appreciate the degree to which coastal habitats and species have been lost, depleted or altered by past human activities, for instance. The use of different fishing gear may also influence the process of LEK generation, thus influencing fishers' perception on fish abundance fluctuations over time (Gerhardinger et al., 2006b). Therefore, we recommend further investigation of how such variation in resource-user's perception of marine resources may influence the documentation of LEK through the use of sketch maps. Further understanding could be achieved by cross comparing different methodological approaches of LEK (e.g., fishers' resource mapping) and conventional ichthyology surveys (e.g., underwater visual census). It is important to note that the idea here is not to test LEK (not even scientific methods generate absolute truths or are error-free), but to create a model that has the capacity to compliment information from different sources.

\section{Goliath grouper spawning aggregations}

We considered a fish aggregation to be formed for reproductive purposes when direct and/or indirect evidence of spawning was recorded (Colin et al., 2003). Direct evidence includes the actual observation of spawning (egg release), females with hydrated eggs and/or the presence of postovulatory follicles in the ovaries of aggregating females. Indirect evidence includes the observation of particular fish behaviors or color patterns (only if these are demonstrably known to be associated with spawning) and swollen abdomen (Colin et al., 2003).

We believe that at least two of the goliath grouper aggregations observed by our informants were spawning aggregations (Fig. 2c, $n=60,20$ and 18; Fig. 2b, $n=30$ and 18). In fact, our spearfisher informants reported that most of the fish caught in these most abundant aggregations had a 
swollen abdomen and well-developed gonads. Distinct female/ male behavior in spawning aggregations was also reported by our senior spearfisher informant (Gerhardinger et al., 2006c). Furthermore, this species does not aggregate throughout the year, and catches in the outer bay area are strongly seasonal (throughout the austral summer, but apparently higher during December) (Gerhardinger et al., 2006b).

Although the large numbers of E. itajara observed in some areas is strong evidence of a spawning aggregation, not all of our records can be defined as so due to the lack of conclusive direct/indirect evidence. Our informants also saw a few small groups (two to four individuals) foraging in the water column, but this could not be linked to spawning purposes.

It was not possible to determine if E. itajara spawning aggregations are formed on a yearly basis at every site considered as a spawning aggregation site. Still, fish spawning aggregation at reef sites can vary on an annual basis and on different spatial scales, according to some of our spearfisher informants. We propose the hypothesis that E. itajara may aggregate at different sites varying on an unknown regional scale. This hypothesis is being assessed by conventional methodologies used in ichthyology studies of spawning aggregations.

Although some long-line fishers have reported catches of up to three E. itajara individuals at once within Babitonga Bay, there is no conclusive evidence regarding direct or indirect observations of mature gonads and/or spawning activity for such reports.

Throughout the Brazilian coast, goliath groupers form groups in numbers varying from a few individuals to dozens in several locations along the coastline (LCG, pers.obs.). The spotting of large aggregations of adults, however, is quite rare nowadays, while small aggregations can still be found in places traditionally known by fishermen and researchers. We believe some of these aggregations are formed for spawning purposes, especially those accounting for a substantial increase in abundance at specific times. The State of Pará in North Brazil had the highest national records of goliath grouper fisheries disembarking from 1998-2002 and during the initial moratorium period (2002-2005) (unpublished data). Higher catch rates occurred during December and March, and there is a notable high abundance of the species at specific fishing spots. For instance, reports from fishermen and local government fisheries authorities indicate capture of more than 20 large adults on a single fishing spot off the State of Maranhão coast.

In Northeast Brazil, off the coast of the State of Sergipe and near the mouth of the São Francisco River, a group of more than 10 adult $E$. itajara has been periodically observed around what is apparently a submerged beach rock reef, located at depths shallower than $30 \mathrm{~m}$, perhaps one of the few hard substrates in that region.

On the coast of the State of Paraná, high abundances of goliath grouper also became frequent in a recently implemented artificial reef system. The surrounding area is a sandy/muddy shelf, where hard substrata are very rare, therefore the implementation of artificial devices created new habitats for goliath groupers (LCG, pers.obs.). Though new diving spots were made available, and goliath grouper sightings have been promoted as a tourist alternative, no evidence has been published so far that this new habitat has produced a net increase in fish biomass. Indeed, this artificial reef site is of conservation concern, as large goliath groupers attracted to these artificial reefs during a significant period of the year have become easy targets for spearfishermen.

Independent of the underlying ecological explanation of the aggregations described herein (foraging, spawning, reef habitat limitation), site-specific conservation measures must be put forward at all sites.

Most of the best known reef fish spawning aggregations in the Atlantic Ocean are reported for the Caribbean Sea (Cornish, 2004). In Brazil, there is evidence that such aggregations are also not uncommon. In fact, there are anecdotal reports of large schools of the cubera snapper Lutjanus cyanopterus sighted along the southeastern Brazilian coast up to the 1970s (Carvalho-Filho, pers. comm.), as well as in northern Brazil in 2005 (Marcovaldi, pers. comm.), and a report of a similar event in South Brazil for this species, provided by one of our informants. Large schools of the dusky grouper Epinephelus marginatus (= Mycteroperca marginata) and the warsaw grouper E. nigritus were also reported by divers and fishers in Brazil (Bertoncini et al., 2003; LCG, pers. obs.). This anecdotal information suggests a large scope for the investigation of reef fish spawning aggregation in Brazil. It is also evident that LEK assessments will be one of the most feasible methods to quickly document such important data (Gerhardinger et al., 2007).

Combining conventional biological surveys with LEK has already been proven to be a viable mechanism for researching and conserving marine fish spawning sites. Aswani and Hamilton (2004), for instance, successfully integrated indigenous ecological knowledge and customary sea tenure with marine and social science for the conservation of a critically endangered species of parrotfish (Bolbometopon muricatum) in the Roviana Lagoon, Solomon Islands.

\section{Methodological remarks}

The reliability of LEK mapping information content presented herein clearly depended on the informant selection process.

The map scale used in this study did not support an exact determination of aggregation localities and species habitat use, but was indeed enough to approximate general occurrence patterns and determine important areas for species conservation. Publicizing the exact location of such aggregations could actually expose them to greater fishing pressure (Sadovy, 2004). Nevertheless, the final map allowed the spatial representation of LEK content in a clear and 


\section{MEROS DO BRASIL NETWORK}
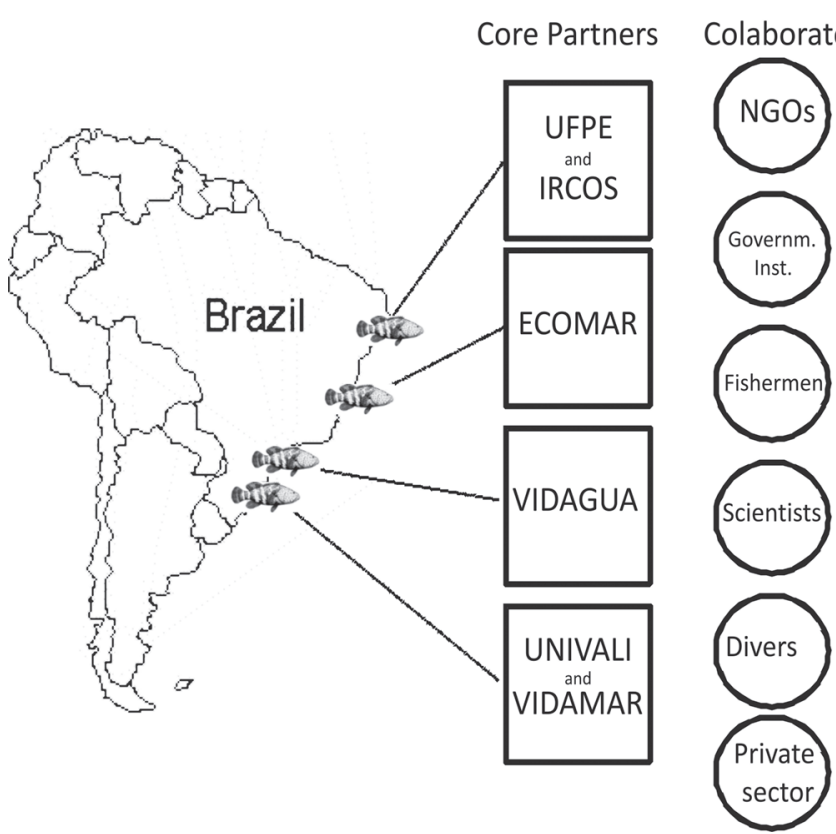

Main Activities

A) Research and Conservation

1) Fishers' local ecological knowledge

2) Participatory monitoring

3) Fisheries biology

4) Conservation Genetics

5) Secondary data gathering

6) Goliath grouper tourism potential

7) Spawning aggregation monitoring

B) Environmental Management

8) Devise of a National Network for Goliath Grouper Conservation

9) Devise of a National Goliath Grouper

Conservation Plan

10) IUCN status evaluation

C) Environmental Education and

Communication

11) Environmental education at fishermen communities

12) Media campaigning

13) Itinerant exhibitions

14) Marine conservation web-page

15) Environmental Education through Art

Fig. 3. Schematic representation of the "Meros do Brasil Network", a multi-institutional partnership promoting coordinated research, environmental education, communication and management actions directed to goliath grouper Epinephelus itajara and mangrove, coral and rocky reef ecosystems in Brazil.

objective way, providing a useful supportive tool (under current use by the environmental authority of the local government) for management and planning decisions regarding the conservation of this particular species in the region. However, it is reasonable to think that science and traditional knowledge are bridging concepts needed for new management approaches where novelty and innovation are key conditions for the sustainability of common resources (Armitage, 2008; Armitage et al., 2007). Therefore, new methodological approaches should be explored in order to link the empirical and qualitative approach of traditional knowledge and quantitative scientific knowledge (Berkes \& Folke, 2002).

\section{Prospects for $E$. itajara conservation in Brazil}

Babitonga Bay is currently a candidate site for a Marine Protected Area (MPA) which will encompass the entire area of our study. The presence of two endangered cetacean species (Pontoporia blainvillei and Sotalia guianensis), together with the presence of the goliath grouper and other endangered species, are the main driving rationale for the creation of this protected area. The results of the present work have been used to guide the process of the area's designation. The foreseen MPA category will allow subsistence and artisanal fisheries to be developed in the area. A local management council will be created, bringing management decisions regarding the use of the area to a local scale. However, many Brazilian MPAs are suffering from a lack of government enforcement, apparently due to the shortage of government financial and logistic support for patrolling. Although this is a no-win situation that requires urgent measures, the engagement of fishers and their LEK as a core component of local management can play an important role in encouraging a stronger partnership among stakeholders for the sustainable use and management of local resources.

The prospect for goliath groupers in Brazil is encouraging, as the endangered status of the species has been acknowledged through a moratorium (2002), recently renewed until 2012. The measure was a result of the work of a group of researchers and managers from universities and NGOs, who have now been joined by other stakeholders, including fishers and other community leaderships and government managers, in a multi-institutional network, namely the Meros do Brasil Network (Fig. 3). The objective of this network is to generate and amass the best available knowledge on the species and its habitat, through a series of actions (Fig. 3), and thus to develop a national strategic plan of action to protect the species and the severely threatened ecosystems it inhabits, such as mangroves, estuaries, and coral and rocky reefs. This network initiative has been articulated since 2002 and now operates at four focal points along the Brazilian coast (Fig. 3), with several local initiatives now starting to take place at other sites (e.g., States of Pará, Maranhão, Sergipe and Espírito Santo). The results of this work will subsidize a national policy 
for the conservation of this endangered marine fish species, which will be drafted in collaboration with the Brazilian governmental environmental agency.

Community collaboration and knowledge was evidently crucial in the development of the first stage of the Meros do Brasil Network (2002-2006) and was defined as a major component of the current stage. Therefore, the project is putting much more effort into trying to develop a parallel program that would improve and maximize the work with local communities and local knowledge. The multi-institutional "Program on Local Knowledge and Practices" was signed in June 2007, and aims to effectively make local knowledge a viable mechanism for marine conservation in Brazil. The implementation of the Program has opened up the possibilities to work not only with goliath grouper research and conservation, but with other important social aspects concerning the sustainability of marine resources in Brazil. One important principle of the Program is to empower LEK systems within current marine management schemes using a dualistic approach, in other words, transferring power while demanding further environmental responsibility from local resource users.

\section{Conclusions}

Goliath grouper spawning aggregations were identified in our study area through LEK evidence of high abundances and spawning activity. This type of knowledge is of fundamental importance for species conservation.

Mapping methodologies can play an important role in surveying LEK, as well as generating new research hypothesis for conventional ichthyologic approaches. Fishers' resource mapping provided a means of exchanging information among various disciplines while maintaining methodological rigor. It also provided a clear way of presenting the data gathered from LEK. Thus, we believe it can facilitate the effective engagement of LEK in the decision-making process of marine conservation initiatives. Furthermore, the simplicity and the short amount of time needed to generate these maps could make this methodology suitable for adaptive co-management approaches, where frequent environmental re-assessments are needed.

The engagement of fishers' LEK is an important component of the ongoing initiative for goliath grouper conservation in Brazil. Thus, the Meros do Brasil Network has the challenge and opportunity to bring the LEK of fishers' onto a broad national scale of conservation research and policy design.

\section{Acknowledgments}

We acknowledge our informants, as well as all other fishers, fishers' associations and fish market staff that contributed their time and knowledge. Comments and suggestions from Sarah Frias-Torres, Michelle Schaerer and two anonymous referees greatly improved the manuscript. This study was made possible due to the financial support from Transpetro Transportes S/A, Padi Aware Foundation, Fundação Biodiversitas, Centro de Estudos Ambientais do Nordeste and Petrobras S/A (Programa Petrobras Ambiental) to the 'Meros do Brasil Network' and the Multi-Institutional Program on Local Knowledge and Practices (www.merosdobrasil.org). These initiatives are co-developed by ECOMAR NGO, Instituto Recifes Costeiros, Universidade Federal de Pernambuco, Instituto Vidágua, Universidade do Vale do Itajaí - Univali and Instituto Vidamar in Santa Catarina State, among other local, national and international partners and collaborators.

\section{Literature Cited}

Anuchiracheeva, S., H. Demaine., G. P. Shivakoti \& K. Ruddle. 2003. Systematizing Local Knowledge Using GIS: Fisheries Management in Bang Saphan Bay, Thailand. Ocean \& Coast Management. 46: 1049-1068.

Armitage, D. 2008. Governance in a multi-level world. International Journal of the Commons, 2(1): 7-32.

Armitage, D., F. Berkes \& N. Doubleday (Eds.). 2007. Adaptive co-management: collaboration, learning and multi-level governance. Vancouver: University of British Columbia Press.

Aswani, S. \& R. J. Hamilton. 2004. Integrating indigenous ecological knowledge and customary sea tenure with marine and social science for conservation of bumphead parrotfish (Bolpometodon muricatum) in the Roviana Lagoon, Solomon Islands. Environmental Conservation 31: 1-15.

Aswani, S. \& M. Lauer. 2006. Incorporating fishermen local knowledge and behavior into geographical information systems (GIS) for designing marine protected areas in Oceania. Human Organization, 65: 81-102.

Baelde, P. 2001. Using Fishers' Knowledge Goes beyond Filling Gaps in Scientific knowledge - Analysis of Australian Experiences. Proceeding of Conference Putting Fishers' Knowledge to Work. University of British Columbia, Florida Center for Reading Research, Pp.78-86.

Begossi, A. 2006. Temporal stability in fishing spots: conservation and co-management in Brazilian artisanal coastal fisheries. Ecology and Society 11(1):1-25.

Berkes, F. \& C. Folke. 2002. Back to the future: ecosystem dynamics and local knowledge. Pp. 121-146. In: Gunderson, L. H. \& C. S. Holling. Panarchy: understanding transformations in human and natural systems. Washington (USA): Island Press.

Bertoncini, A. A., L. F. Machado, M. Hostim-Silva \& J.P. Barreiros. 2003. Reproductive biology of the dusky grouper Epinephelus marginatus (Lowe, 1834). Brazilian Archives of Biology and Technology, 46(3): 373-381.

Calamia, M. A. 1999. A methodology for incorporating traditional ecological knowledge with geographic information systems for marine resource management in the Pacific. SPC Traditional Marine Resource Management and Knowledge Information Bulletin, 10: 2-12.

Colin, P. L., Y. J. Sadovy \& M. L. Domeier. 2003. Manual for the Study and Conservation of Reef Fish Spawning Aggregations. Society for the Conservation of Reef Fish Aggregations Special Publication No. 1 (Version 1.0). 
Cornish, A. 2004. Development and Summary of Global Database, July 2004. Society for the Conservation of Reef Fish Spawning Aggregations.

Costa-Neto, E. M.,C. V. Dias \& M. N. Melo. 2002. O conhecimento ictiológico tradicional dos pescadores da cidade de Barra, região do médio São Francisco, Bahia, Brasil. Acta Scientiarum, 24(2): 561-572.

Craig, M.T., R. T. Graham, R. A. Torres, J. R. Hyde, M. O. Freitas, B. P. Ferreira, M. Hostim-Silva, L. C. Gerhardinger, A. A. Bertoncini \& D. R. Robertson. 2008. How many species of goliath grouper are there? Cryptic genetic divergence in a threatened marine fish and the resurrection of a geopolitical species. Endangered Species Research, preprint, 1-8.

Davis, A. \& J. R. Wagner. 2003. Who knows? On the importance of identifying "experts" when researching local ecological knowledge. Human Ecology, 31(3): 463-489.

Diegues, A. C \& R. S. V. Arruda. 2001. Saberes Tradicionais e biodiversidade no Brasil. (Biodiversidade 4). Ministério do Meio Ambiente, Brasília, São Paulo: USP, 176p.

Domeier, M. L. \& P. L. Colin. 1997. Tropical reef fish spawning aggregations: defined and reviewed. Bulletin of Marine Science. 60(3): 698-726.

Drew, J. 2005. Use of Traditional Ecological Knowledge in Marine Conservation. Conservation Biology, 19(4): 1286-1293.

Frias-Torres, S. 2006. Habitat use of juvenile goliath grouper Epinephelus itajara in the Florida Keys, USA. Endangered Species Research, 2: 1-6.

Gerhardinger, L. C., A. A. Bertoncini \& M. Hostim-Silva. 2006c. Local ecological knowledge and Goliath grouper spawning aggregations in the South Atlantic Ocean: Goliath grouper spawning aggregations in Brazil. SPC Traditional Marine Resource Management and Knowledge Information Bulletin, 20: 33-34.

Gerhardinger, L. C., M. O. Freitas, R. P. Medeiros, E. A. Godoy, R. C. Marenzi \& M. Hostim-Silva. 2007. Local Ecological Knowledge on the Planning and Management of Marine Protected Areas and Conservation of Fish Spawning Aggregations: The Experience of "Meros do Brasil" Project. Pp. 117-139. In: MMA, Áreas Protegidas do Brasil 4. Brasília, 271p.

Gerhardinger, L. C., M. Hostim-Silva, R. Medeiros \& R. C. Marenzi. 2006a. Conhecimento Ecológico Local de Pescadores da Baía Babitonga, Santa Catarina, Brasil: Peixes da Família Serranidae. Acta Scientiarum Biological Science. 28(3): 253-261.

Gerhardinger, L. C., R. Medeiros., R. C. Marenzi., A. A. Bertoncini \& M. Hostim-Silva. 2006b. Local Ecological Knowledge on the Goliath Grouper Epinephelus itajara. Neotropical Ichthyology. 4(4): 441-450.

Haggan, N., B. Neis \& I. G. Baird. 2007. Fishers' Knowledge in Fisheries Science and Management, Coastal Management Sourcebooks 4, UNESCO LINKS, Paris.

Hamilton, R. \& R. Walter. 1999. Indigenous ecological knowledge and its role in fisheries research design: A case study from Roviana Lagoon, Western Province, Solomon Islands. SPC Traditional Marine Resource Management and Knowledge Information Bulletin, 11: 13-25.

Hostim-Silva, M., A. A. Bertoncini., L. C. Gerhardinger \& L. F. Machado. 2005. The Lord of the Rocks conservation program in Brazil: the need for a new perception of marine fishes. Coral Reefs. 24: 74.

Huntington, H. P. 2000. Using Traditional Ecological Knowledge in Science: Methods and Applications. Ecological Applications,
10(5): 1270-1274.

Ibama (Instituto Brasileiro do Meio Ambiente e dos Recursos Naturais Renováveis). 1998. Proteção e controle de ecossistemas costeiros: Manguezal da Baía da Babitonga. Brasília: Ibama. Coleção Meio Ambiente, Série Estudos de Pesca, 146p.

Johannes, R. E. 1998. The case for data-less marine resource management: examples from tropical nearshore finfisheries. Trends in Ecology \& Evolution, 13: 243-246.

Koenig, C. C, F. C. Coleman, A. M. Eklund, J. Schull \& J. Ueland. 2007. Mangroves as essential nursery habitat for goliath grouper (Epinephelus itajara), Bulletin of Marine Science, 80(3): 567-586.

Langley, J. 2006. Vezo Knowledge: Traditional Ecological Knowledge in Andavadoaka, southwest Madagascar. Blue Ventures Conservation Report.

Neis, B., D. C. Schneider., L. Felt., R. L. Haedrich., J. Fischer \& J. A. Hutchings. 1999. Fisheries assessment: what can be learned from interviewing resource users? Canadian Journal of Fisheries and Aquatic Sciences, 56(10): 1949-1963.

Pauly, D. 2005. Anecdotes and the shifting baseline syndrome of fisheries. Trends in Ecology \& Evolution, 10(10): 430.

Paz, V. A. \& A. Begossi.1996. Ethnoichthyology of Gamboa Fishermen of Sepetiba Bay, Brazil. Journal of Ethnobiology, 16(2):157-168.

Pinheiro, L. \& M. Cremer. 2004. Sistema pesqueiro da Baía de Babitonga, litoral norte de Santa Catarina: uma abordagem etnoecológica. Desenvolvimento e Meio Ambiente, 8: 59-68.

Pinnegar, J. K. \& G. H. Engelhard. 2008. The 'shifting baseline' phenomenon: a global perspective. Reviews in Fish Biology and Fisheries, 18: 1-16.

Roberts, C. 2007. The Unnatural History of the Seas. Washington DC, Island Press, 435p.

Ruddle, K. 1994. Local Knowledge in the future management of inshore tropical marine resources of inshores tropical marine resources and environments. Nature and Resources, 30(1): 28-37.

Sadovy, Y. 2004. The Science and Policy of Protecting Spawning Aggregations: Interview with Yvonne Sadovy, Society for the Conservation of Reef Fish Aggregations. Marine Protected Areas News, Washington. 4-5.

Sadovy, Y. \& A. M. Eklund. 1999. Synopsis of biological data on the Nassau grouper, Epinephelus striatus (Bloch 1792) and the jewfish E. itajara (Lichtenstein 1822). NOAA Technical Report NMFS, 146p.

Sáenz-Arroyo, A., C. M. Roberts., J. Torre., M. Carino-Olivera \& R. R Enrýq. 2005. Rapid environmental shifting baseline among fishers from the Gulf of California. Proceedings of the Royal Society, 272: 1957-1962.

Sala, E., O. Aburto-Oropeza., G. Paredes \& G. Thompson. 2003. Spawning aggregations and reproductive behavior of reef fishes in the Gulf of California. Bulletin of Marine Science. 72(1): 103 $-121$.

Seixas, C. S. \& F. Berkes. 2003. Dynamics of socio-ecological changes in a lagoon fishery in southern Brazil. Pp. 271-298. In: Berkes, F.; J. Colding \& C. Folke (Eds.). Navigating socio-ecological systems: building resilience for complexity and change. Cambridge: Cambridge University Press.

Silvano, R. A. M., P. F. L. MacCord, P. F. L. Lima \& A. Begossi. 2006. When Does this Fish Spawn? Fishermen's Local Knowledge of Migration and Reproduction of Brazilian Coastal Fishes. Environmental Biology of Fishes, 76(2-4): 371-381.

Tak-Chuen, C. T \& B. P. Ferreira. 2006. Epinephelus itajara. In: IUCN 2007. 2007 IUCN Red List of Threatened Species. 
<www.iucnredlist.org>. Downloaded on 14 February 2008.

Univali (Universidade do Vale do Itajaí). 2002. Boletim estatístico da pesca industrial de Santa Catarina - Ano 2001: ações prioritárias ao desenvolvimento da pesca e aqüicultura no sul do Brasil. UNIVALI, Pró-Reitoria de Ensino, Centro de Educação Superior de Ciências Tecnológicas, da Terra e do Mar. Itajaí, $93 \mathrm{p}$.

Accepted November 2008

Published March 31, 2009 